\title{
Výplň týlní deprese sesuvu mezi Židlochovicemi a Blučinou na severozápadním okraji Výhonu
}

\author{
Quaternary depression behind lanslide front between Židlochovice and Blučina \\ on northwestern margin of the Výhon hillock
}

\section{Martin Hanáček ${ }^{1,2} \rightrightarrows$, Jan Petřík ${ }^{3}$, Jarmila Bíšková4, Richard Bíško4, Katarína Adameková ${ }^{3}$, Zuzana Lendáková ${ }^{5}$}

\author{
'Geografický ústav, Prírodovědecká fakulta, Masarykova univerzita, Kotlářská 267/2, 61137 Brno, Česká republika \\ 2 Vlastivědné muzeum Jesenicka, p. o., Zámecké náměstí 1, 79001 Jeseník, Česká republika \\ ${ }^{3}$ Ústav geologických věd, Prírodovědecká fakulta, Masarykova univerzita, Kotlářská 267/2, 61137 Brno, Česká republika \\ ${ }^{4}$ Ústav archeologické památkové péče Brno, v. v. i., Kaloudova 1321/30, 61400 Brno, Česká republika \\ ${ }^{5}$ Katedra geologie, Př́rodovědecká fakulta Univerzita Palackého, 17. listopadu 1192/12, 77146 Olomouc, Česká republika
}

\section{Key words:}

Radiocarbon dating, ERT survey, lake and wetland deposits, slope deposits, landslides, Cézavy site, Bronze Age

$凸$ HanacekM@seznam.cz; geolog@muzeumjesenik.cz

Editor:

Pavla Tomanová Petrová

\begin{abstract}
The studied area is located in a small saddle between Strže (Cézavy) ridge and Výhon hill. Morphology of explored area originated during large landslide. The landslide front formed the Strže (Cézavy) ridge. Landslide scarp gave shape to the slope of Výhon hill. Studied saddle lies between the lanslide front and the scarp. The saddle actually forms a small depression suitable for accumulation of Quaternary (Holocene) sediments. The "Cézavy" site is an important Bronze Age settlement. Geological setting was examined in situ by evaluation of the bore hole cores and electric resistivity tomography. Selected horizons were dated by C14 method. Holocene infill of the depression is composed of two sedimentary units: central facies of dark coloured lacustrine-swamp clayey-silty sediments and marginal facies of clayey-silty-sandy sediments. Depression of assymetrical shape is deepest near SE foothill of the Cezávy ridge (directly behind the landslide front), where started infilling as soon as $\sim 3600$ BP or earlier. The Quaternary infill of the depression is underlain by bodies of Miocene (Badenian) rocks. Geochronological model shows existence of swamps-lacustrine basins in a time span since 17th century BC till 18th century AD. Local morphology in depression is caused by minor landslides which originated from primary scarp (Výhon hill slope). Last significant events were probably extensive, historically recorded landslides in 70 's of 18th century. Recent morphology was formed as late as in 19th century.
\end{abstract}

Úvod a lokalita

Trat Cézavy je známou archeologickou lokalitou s doloženým lidským osídlením již ve starší době bronzové. Systematický archeologický výzkum započatý v polovině 20. století postupně doplnily výsledky radiokarbonového datování, antropologie, izotopové analýzy, archeozoologie, malakozoologie, sedimentologie a geofyziky (shrnutí viz Salaš et al. 2012).

Lokalita se nachází mezi Židlochovicemi a Blučinou, asi $13 \mathrm{~km}$ j. od Brna. Spočívá na sz. úbočí až úpatí Výhonu, který se v těchto místech zvedá nad kvarterní nivy Litavy (v tomto úseku též nazývané Cézava) a Svratky (obr. 1). Studovanou lokalitou je sedlo mezi prudkým svahem Výhonu (trat Nové hory, 330 m n. m., obr. 1, 2A) a mnohem nižším, úzkým hřebenem Strže (trat Cézavy, 258,4 m n. m., obr. 1, 2D, E). Sedlo leží v nadmořské výšce 240 m a má podobu malé bezodtoké deprese.

Předkvarterní podklad zájmové oblasti budují miocenní (spodnobadenské) jíly s polohami vápnitých pískovců (Vrtek 1978; Pálenský 1997). Celá zájmová oblast představuje mohutný sesuv s odlučnou plochou v sz. svahu Výhonu (Nové hory). Samotný sesuv tvoří hřbet Cézav, jeho sz. úpatí a rovněž sedlo mezi 


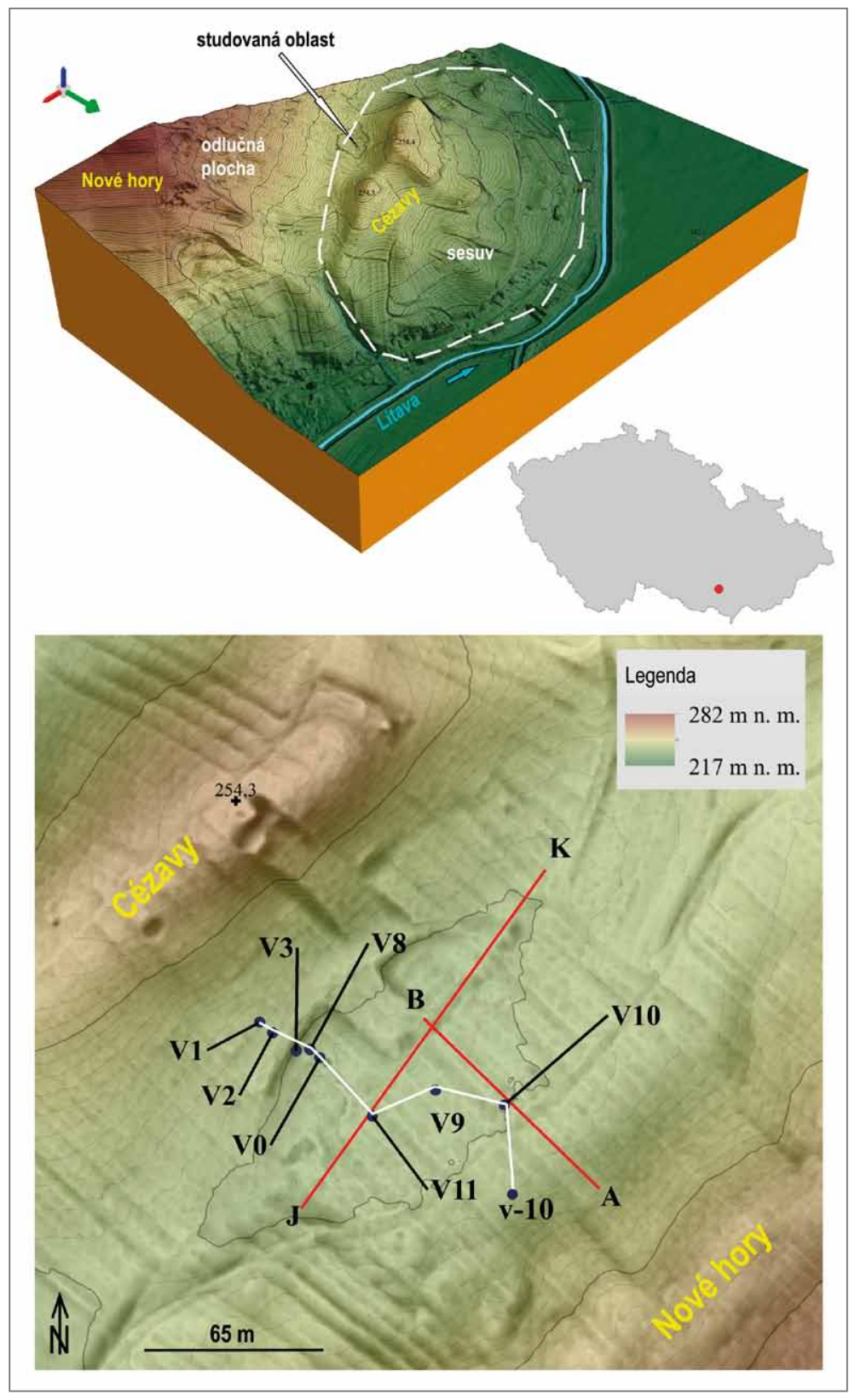

Obr. 1: 3D model studované oblasti a mapa studované oblasti s vyznačením vrtů a sond, geologického řezu (bílá linie) a ERT profilů (linie A-B, J-K). Typy vrtů a sond: V0 a V8 - kopané sondy, V10 a V11 - strojové vrty, V1, V2, V3 a V9 - ruční vrty, v-10 strojní vrt z archivní dokumentace (Vrtek 1978).

Fig. 1: 3D model of studied area and map of studied area with location of cores, geological cross-section (white line), and ERT profiles (A-B, J-K lines). Core types: V0 and V8 - excavated probes, V10 and V11 - drillings, V1, V2, V3 and V9 - soil probes, v-10 drill core from archive documentation (Vrtek 1978).

pravděpodobně zapříčiňují pevné miocenní pískovce, vystupující přímo ve stěnách (výřez v obr. 2D). Tělesa sesuvů mají bud' lehce zvlněnou morfologii (obr. 2E), nebo se na jejich povrchu objevují vysloveně lokální, proti okolí výrazně zahloubené deprese (obr. 2F). Tyto deprese částečně ohraničují bloky pískovců. Zcela čerstvé odlučné plochy s geliflukční aktivitou dnes pozorujeme pouze v nejvyšší části Nových hor (výřezy v obr. 2B), kde patrně vznikají i v pleistocenních eolických praších, pokrývajících přilehlé temeno Výhonu (Pálenský 1997).

V sedle mezi Novými horami a Cézavami byly $\mathrm{v}$ podloží svahovin odkryty tmavě zbarvené sedimenty, bohaté organickou hmotou, které se $\mathrm{v}$ některých obdobích vývoje ukládaly $\mathrm{v}$ mokřadech a vodní nádrži, což prokázala analýza malakozoologických společenstev (Bíšková 2014). V těchto jezerních a mokřadních sedimentech byly objeveny kosterní pozůstatky z mladší doby bronzové a radiokarbonové datování vymezilo depozici těchto sedimentů časově velmi široce od 3600 př. n. l. do 18. století n. l. Nadložní svahoviny obsahovaly jen novověkou keramiku (Salaš et al. 2012). Provedené výzkumy se soustředily především na sz. část sedla, podél úpatí Cézav. Předkládaná studie se pokouší rekonstruovat stavbu, hlavní fáze vývoje a zjistit řídící činitele vývoje deprese (sedla) na základě jedenácti vlastních vrtů (V0-V11) a dvou ERT profilů.

\section{Metodika}

Za účelem litostratigrafického vyhodnocení lokality byly pořízeny kopané sondy (V0 a V8), strojové vrty (V10 a V11) a ruční vrty (V1, V2, V3 a V9). Ruční vrty byly zhotoveny vrtákem se sondážní tyčí. Strojové vrty byly zhotoveny jednoduchým jádrovákem, osazeným roubíkovými korunkami v řezném průměru $156 \mathrm{~mm}$. Radiokarbonové datování bylo provedeno v laboratoři v Poznani (Poznan Radiocarbon Laboratory), viz tab. 1. Pro elektrickou

Cézavami a Výhonem (https://mapy.geology.cz/svahove_ nestability/). Samotná studovaná lokalita se nachází v týlní části sesuvového tělesa. Hlavním typem kvartérních depozit jsou svahové sedimenty. Morfologie Nových hor jasně prozrazuje, že po prvotní obrovské sesuvné události byly i nadále jejich rozhodujícím morfotvorným činitelem kvartérní svahové pohyby. Převažují pozvolnější sesuvy vjílovitých nezpevněných horninách s nižšími odlučnými plochami a větším plošným rozsahem (obr. $2 \mathrm{~B}, \mathrm{C})$. Mohutné sesuvy se místy projevují nápadně vysokými, rovnými odlučnými plochami (obr. 2D). Strmost odlučných ploch odporovou tomografii (ERT) byl použit automatický geoelektrický systém ARES (GF Instruments, s. r. o., ČR). Měřící elektrody byly zapojeny $\mathrm{v}$ uspořádání Wenner-Schlumberger. Rozteče elektrod podél profilů, celkové délky profilů, maximální hloubkový dosah a hodnoty maximální chyby RMS jsou uvedeny v tabulce 2 . Naměřená data byla zpracována metodou inverze nejmenších čtverců v softwaru RES2DINV (Geotomo, Malaisie) a zobrazena jako inverzní modely měrného odporu. Topografická data zohledněná $\mathrm{v}$ profilech byla získána $\mathrm{z}$ DMR čtvrté generace (ČUZK). 
Tab. 1: Radiokarbonová data.

Tab. 1: Radiocarbon dating.

\begin{tabular}{|c|c|c|c|c|c|c|}
\hline Vzorek & Vrt/Sonda & $\begin{array}{l}\text { Hloubka } \\
(\mathrm{cm})\end{array}$ & Laboratorní kód & 14C Age BP & $\begin{array}{c}\text { 14C kalibrováno } \\
(95,4 \%)\end{array}$ & Citace \\
\hline Blucina 2016 & V9 & 340 & Poz-88839 & $280 \pm 30$ & $1498-1795$ AD & \\
\hline Blucina_jezero_1 & V8 & 380 & Poz-52332 & $650 \pm 25$ & $1282-1393 \mathrm{AD}$ & Bíšková, 2014 \\
\hline Blucina_jezero_2 & V8 & 300 & Poz-52333 & $545 \pm 25$ & $1318-1432 \mathrm{AD}$ & Bíšková, 2014 \\
\hline Blucina 3 & V0 & 390 & Poz-41673 & $3345 \pm 30$ & $1735-1532 \mathrm{BC}$ & Salaš et al., 2012 \\
\hline Blucina 4 & V0 & 325 & Poz-41674 & $1365 \pm 30$ & 611-761 AD & Salaš et al., 2012 \\
\hline Blucina_1_340 & V10 & 340 & DeA-22512 & $2124 \pm 46$ & $356-40 \mathrm{BC}$ & \\
\hline Blucina_1_390 & V10 & 390 & DeA-23189 & $2817 \pm 43$ & $1109-848$ BC & \\
\hline \multirow[t]{2}{*}{ Blucina_2_290 } & \multirow[t]{2}{*}{ V11 } & \multirow[t]{2}{*}{290} & \multirow[t]{2}{*}{ DeA-23187 } & $\begin{array}{l}\text { Nezuhelnatělý } \\
\text { vzorek, malý } \\
\text { podíl uhlíku } \\
<1 \% \text { C }\end{array}$ & $\begin{array}{l}\text { Nespolehlivý } \\
\text { výsledek: }\end{array}$ & \\
\hline & & & & $712 \pm 42$ & $1223-1388 \mathrm{AD}$ & \\
\hline Blucina_2_330 & V11 & 330 & DeA-23190 & $659 \pm 40$ & $1274-1397 \mathrm{AD}$ & \\
\hline
\end{tabular}

až tmavě šedou barvou (obr. 5). $\mathrm{V}$ sondě V0 byly makroskopicky zaznamenány karbonátové povlaky svislých ka nálkových struktur, které prostupují facii 2 rovněž ve vrtech V10 a V11 (obr. 5E). Facie 2 neobsahuje makroskopicky odlišitelné hrubší polohy

Tab. 2: Parametry ERT profilů.

Tab. 2: ERT profiles parameters.

\begin{tabular}{|l|c|c|c|c|}
\hline Profil & $\begin{array}{c}\text { Délka profilu } \\
(\mathrm{m})\end{array}$ & $\begin{array}{c}\text { Rozteč elektrod } \\
(\mathrm{m})\end{array}$ & $\begin{array}{c}\text { Maximální hloubka } \\
(\mathrm{m})\end{array}$ & $\begin{array}{c}\text { RMS } \\
(\%)\end{array}$ \\
\hline A-B & 95 & 1 & 18 & 1,3 \\
\hline J-K & 157,5 & 2,5 & 35 & 1,8 \\
\hline
\end{tabular}

\section{Výsledky}

V prostoru sedla byla vyhloubena ručně kopaná son$\mathrm{da}(\mathrm{V} 0)$, pořízeno devět ručních vrtů (pro různou kvalitu vyvrtaného jádra byly pro rekonstrukci a datování využity vrty V1, V2, V3, V8 a V9), dva strojní vrty (V10, V11, obr. 3,4$)$. Všechny vrty odhalily shodnou superpozici tří facií (obr. 5, 6), které se makroskopicky vzájemně odlišují především podílem organické hmoty a mírou recentní nebo subfosilní bioturbace. Nejkvalitnější informace poskytly jádrové vrty V10 a V11. Facie jsou očíslovány od nejmladší po nejstarší, aby při potenciálním dalším vrtání v budoucnosti bylo možno vymezovat nové, ještě starší facie. Výsledky radiokarbonového datování ukazuje tabulka 1. Bylo provedeno měření dvou ERT profilů (profil AB, profil JK), viz tab. 2 a obr. 7.

\section{Facie 1}

Facie 1 byla zachycena ve svrchní části každého vrtu (obr. 5). Jedná se o hnědošedý prachovito-jílovitý sediment s masivní texturou a občasnými písčitými polohami. Povrch facie je tvořen humózním půdním horizontem s kořeny rostlin, které pronikají celou mocností facie 1 (obr. 5B, G). Nad bází facie byly ve vrtu V10 zjištěny neostře ohraničené útržky tmavě šedého prachovito-jílovitého sedimentu (modrá šipka v obr. 5D). V sondě V0 zahrnovala facie 1 neprůběžné, šmouhovité laminy a vrstvy jemnozrnného písku mocné do $3 \mathrm{~cm}$. Rozptýleně se ve facii 1 vyskytují drobné uhlíky a fragmenty schránek měkkýšů. Maximální zjištěné mocnosti 3,3 m dosahuje facie 1 ve vrtu V10 na úpatí Nových hor (obr. 6). Směrem do centra deprese mocnost klesá na 2,5-2,7 m (V9, V11). Tato hloubka se udržuje až na úpatí Cézav (V0-V1).

\section{Facie 2}

Facie 2 je reprezentována masivním prachovito-jílovitým sedimentem, nápadným svou tmavě hnědou se objevují jednotlivé velké klasty pískovce (V10, obr. 5E). Hojně se vyskytují schránky měkkýšů. Mocnost facie 2 je velmi variabilní (obr. 6). Maximální zachycené hodnoty $\sim 2,8 \mathrm{~m}$ dosahuje $\mathrm{v}$ sondě V0 na úpatí Cézav, tedy na sz. okraji deprese. Směrem do centra deprese klesá mocnost na $\sim 1,5 \mathrm{~m}$ (V9) a $\sim 0,75 \mathrm{~m}$ (V11). Mocnost $\sim 0,75 \mathrm{~m}$ byla zastižena na jv. okraji deprese, tedy na úpatí Nových hor.

\section{Facie 3}

Facie 3 je tvořena masivním šedožlutým jílem s pseudomycéliemi a nepravidelnými písčitými polohami (obr. 5). Ve vrtu V11 je jíl zřetelně písčitější než ve vrtu V10. Povrchová zóna facie 3 ve vrtu V10 se odlišuje od zbylé, hlubší části facie. Je mocná přibližně $10 \mathrm{~cm}$, má drobtovitou strukturu a tmavě hnědou barvu (bílá šipka v obr. 5C). Jíl pod touto zónou je prostoupen svislými, kosými i vodorovnými šmouhami tmavě hnědé barvy, bohatý organickým materiálem. S rostoucí hloubkou pod drobtovitým tmavým horizontem hustota i barevná intenzita šmouhování klesá, až se šmouhy nakonec zhruba $\mathrm{v}$ hloubce $1,2 \mathrm{~m}$ pod drobtovitým horizontem úplně vytrácí (střední a spodní část vrtného jádra na obr. 5C). $\mathrm{S}$ hloubkou se barva jílu mění $\mathrm{z}$ hnědé na šedožlutou. Ve vrtu V11 je povrchová zóna jílu rovněž drobtovitá a tmavě hnědě zbarvená (bílá šipka v obr. $5 \mathrm{H}$ ). Šmouhování v jejím podloží je jemné a do hloubky přibližně $30 \mathrm{~cm}$ rychle vyznívá (žlutá šipka v obr. $5 \mathrm{H}$ ). V obou vrtech jsou si tedy povrchové zóny facie 3 podobné, odlišují se však mocností a velikostí pozorovaných jevů.

\section{Facie 4}

Facie 4 je tvořena písčitým prachem, který je vázaný pouze na vrty V1 a V2 na úbočí Cézav. Jako jediná $\mathrm{z}$ facií nebyla zachycena $\mathrm{v}$ prostoru celé deprese. Mocnost nepřekračuje $\sim 0,75 \mathrm{~m}$.

\section{ERT profily}

Měrné odpory $\mathrm{v}$ profilech se pohybují v rozmezí 5-36 $\Omega \mathrm{m}$ a spadají tak do nízkých odporů relativně vodivých hornin [např. Mussett a Khan (2000) uvádějí pro jíly rozmezí 1-100 $\Omega \mathrm{m}$, Everett (2013) uvádí pro jíly rozmezí $1-20 \Omega \mathrm{m}$ a $20-200 \Omega \mathrm{m}$ pro písky (mokré až 

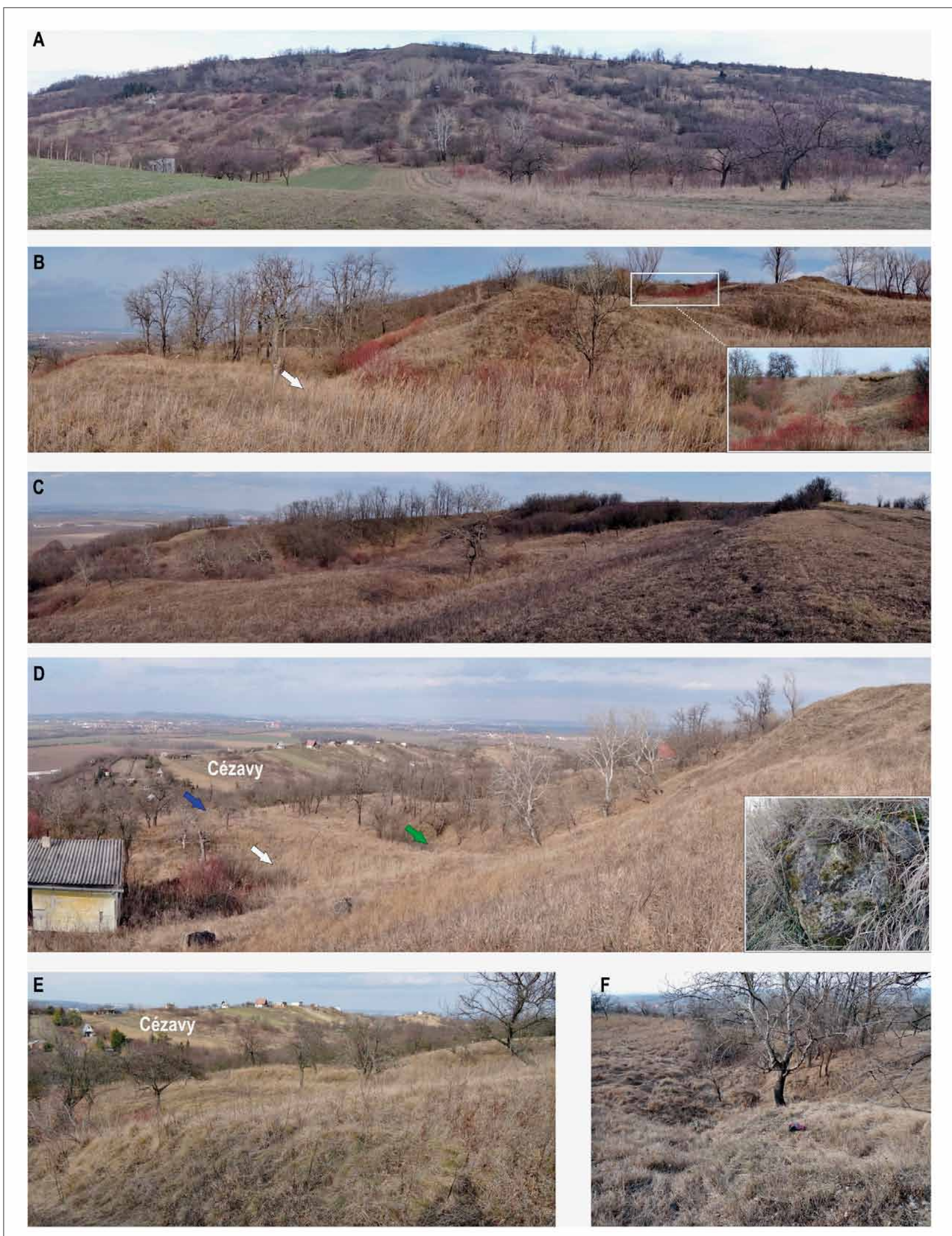

Obr. 2: Fotodokumentace lokality. A - Pohled z Cézav na Nové hory. B - Svrchní část svahu Nových hor. Bílá šipka - mokřady. Výřez: geliflukce na nejmladších odlučných plochách. C - Rozlehlé sesuvy s nízkou odlučnou plochou těsně pod temenem Výhonu. D - Sesuv s vysokou odlučnou plochou v úbočí Nových hor. Bílá šipka - mokřady, modrá šipka - obr. E, zelená šipka - obr. F. Výřez: blok vápnitého pískovce ve vysoké odlučné ploše sesuvu. E - tělesa sesuvů v úbočí Nových hor. F - Hluboká, jasně ohraničená prohlubeň v tělese sesuvu.

Fig. 2: Photo documentation of the site. A - View of the Nové hory from Cézava. B - The upper part of the slope of the Nové hory. White Arrow - Wetlands. Cut-out: gelifluction avtivity on youngest scarps. C - Large landslides with low scarp just below the summit of the Výhon. D - Landslide with high scarp on the slopes of the Nové hory. White arrow - wetlands, blue arrow - location of Fig. E, green arrow - location of Fig. F. Cut-out: block of calcareous sandstone in a high scarp of landslide. E - landslide bodies in the slopes of the Nové hory. F - Deep, clearly bordered depression in the landslide body. 


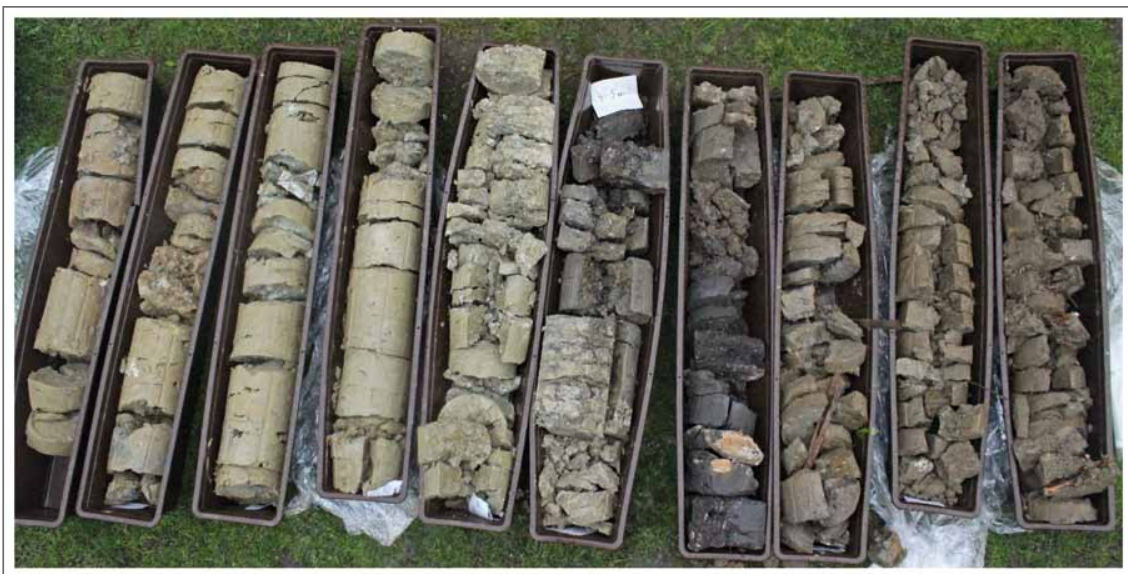

Obr. 3: Jádro vrtu V10.

Fig. 3: Photography of core V10.

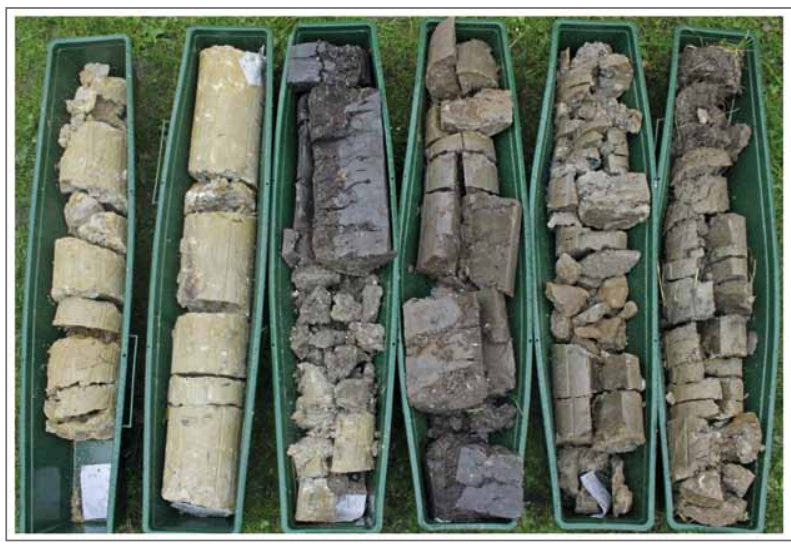

Obr. 4: Jádro vrtu V11.

Fig 4: Photography of core V11.

suché) a Štěpančíková et al. (2011) uvádí měřené odpory pro miocenní jílovité sedimenty $0-40 \Omega \mathrm{m}$ ]. V profilech lze měrné odpory rozdělit do tří hlavních domén: doména 1 (odpory 0-10 $\Omega \mathrm{m}$ ), doména 2 (odpory 10-20 $\Omega \mathrm{m}$ ) a doména 3 (odpory 20-35 $\Omega \mathrm{m}$ ), viz obr. 7 .

$\mathrm{V}$ obou profilech dosahuje největšího rozsahu i hloubky doména 1 , vyplňující především centrum deprese (obr. 7). Při periferiích deprese v profilech $\mathrm{AB}$ i JK se objevují zóny reprezentované doménou 2 . V centrální části profilu JK a těsně pod povrchem terénu celého profilu $\mathrm{AB}$ kontinuálně probíhá tenká zóna reprezentovaná doménou 3.

\section{Interpretace a diskuze Vznik facií}

Intraklasty tmavých sedimentů z podložní facie 2 bezprostředně nad bází a masivní textura s písčitými polohami naznačují, že facie 1 vznikla jako zředěný bahnotok (Karkanas et al. 2018). Jednalo se o jílovitý sesuv (Clay flow slide podle Hungra et al. 2001). Při tomto typu sesuvů dochází $\mathrm{k}$ destabilizaci stále vnitřnějších částí výchozí elevace. Přenos destabilizace se projevuje sérií dílčích odlučných ploch, následujících po sobě do vyšších částí svahu. Morfologie Nových hor odpovídá popsanému procesu. Makroskopická podobnost se spodnobadenskými jíly ukazuje na tyto sedimenty jako na zdroj materiálu facie 1 . Tomu nasvědčuje i složení malakofauny, která kromě holocenních terestrických a sladkovodních taxonů obsahuje i miocenní marinní redeponovaný materiál (Bíšková 2014). Uhlíky jsou pozůstatky plošné a dlouhodobé antropogenní aktivity v oblasti a součástí svahovin se staly během gravitační destabilizace obhospodařovaných svahů Nových hor (Salaš et al. 2012). Povrchová zóna facie 1 je postižena pedogenetickými procesy (povrchový humózní A-horizont a v jeho podloží prokořeněný B-horizont půdního profilu).

Tmavé zbarvení i masivní stavba facie 2 dokládají zamokřené nebo subakvatické prostředí, ve kterém nedocházelo k rozkladu organického materiálu. Karbonátové povlaky vyplnily kanálky po rozložených koříncích rostlinstva. Malakozoologická analýza identifikovala v této facii prrítomnost společenstva vyžadující vodní hladinu (Bíšková 2014). To znamená, že facie 2 vznikla v jezerním či mokřadním prostředí. Jelikož sedimenty jsou jílovitoprachovité a do deprese neústil žádný tok, byly zdrojem materiálu svahové bahnotoky z okolních elevací, tj. starší genetické ekvivalenty mladší facie 1 .

Facie 3 je interpretována jako spodnobadenské jíly („tégly“) a tedy miocenní podloží kvartérní deprese. Na povrchu jílů se vytvořila půda, která byla uložením facie 2 zakonzervovaná do podoby pohřbené půdy (Smolíková 1988; Němeček et al. 1990). Má vyvinutý tmavě hnědý horizont drobtovité struktury, který ve facii 3 dosahuje mocnosti $\sim 10 \mathrm{~cm}$. V půdním horizontu jsou patrné stopy prokořenění, které zasahuje až do podložních jílů, kde se projevuje sporadickou prrítomností rozložených organických zbytků. Přítomnost redoximorfních prvků svědčí o periodickém povrchovém provlhčení (Němeček et al. 1990) vrchní části facie 3.

Hrubozrnější písčitá facie 4 při okraji pánve může odpovídat svahovině se zdrojem materiálu v prostoru pravěkého hradiska na hřebenu Strže (Salaš et al. 2012).

\section{Korelace vrtů a ERT profilů}

Z proložení vrtu V10 a ERT profilu AB vyplývá, že na základě odporové metody není možné v tomto řezu odlišit miocenní sedimenty od kvarterní výplně (obr. 7). "Tégly“, facie 2 i spodní polovina facie 1 spadají do pole domény 1. Proložení vrtu V11 do ERT profilu JK ukazuje jasnou korelaci „téglü“ s ostře omezeným tělesem tvořeným odpory domény 2 . Rozdílný projev „téglü“ v těchto dvou ERT profilech je výsledkem zřetelně vyšší písčitosti sedimentů ve vrtu V11 oproti vrtu V10.

Na základě srovnání obou ERT profilů s vrty je možné předpokládat, že rozsáhlé pole domény 1 zahrnuje spodnobadenské jíly a jílovité kvartérní sedimenty (jezerní a mokřadní uloženiny a z jílovitých zdrojů derivované svahoviny). Doména 2 vymezuje bud’ písčitější 


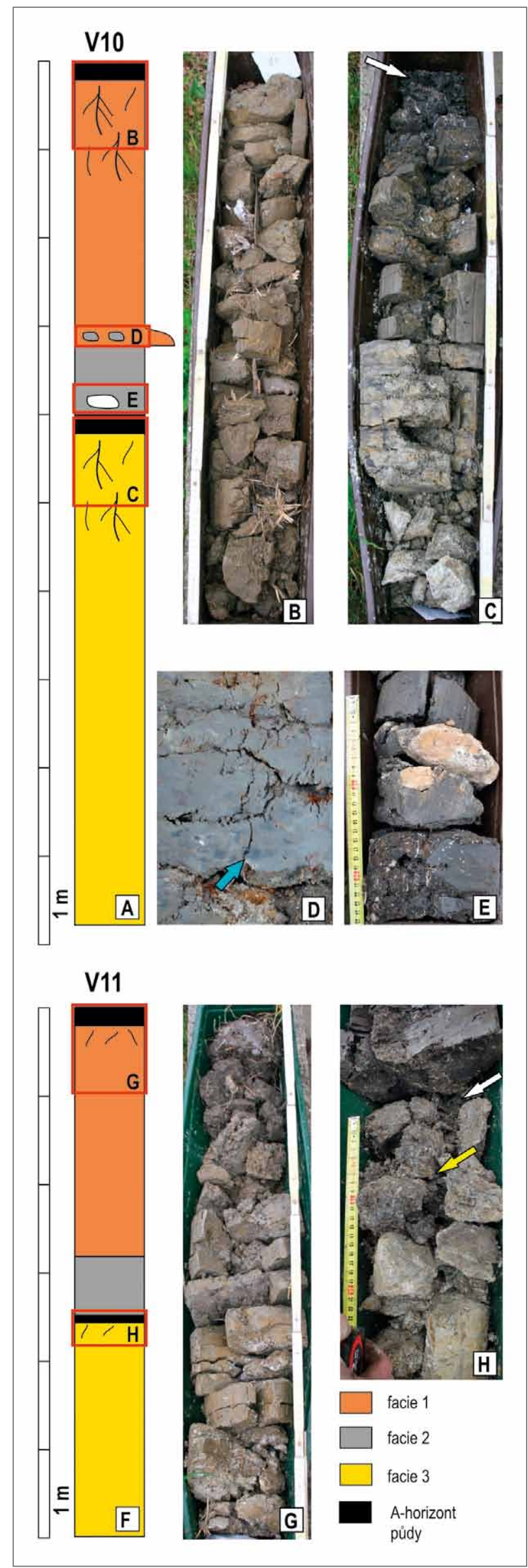

miocenní sedimenty nebo mělce podpovrchové svahoviny. $\mathrm{K}$ nim lze přiřadit i protáhle těleso při s. okraji profilu $\mathrm{AB}$ (ve svahu Nových hor) reprezentované doménou 2 (šipka v profilu $A B$ na obr. 7). Na základě protažení směrem do centra deprese a polohy v nadloží sedimentů domény 1 je možné těleso interpretovat jako sesuv. Těleso na j. okraji profilu $\mathrm{AB}$ reprezentované doménou 2 je budto sesuv derivovaný z Cézav nebo, vzhledem k uložení pod sedimenty domény 1 , blok rigidnější horniny v jílu.

\section{Tvar a vývoj deprese}

Deprese je jasně vymezena na sz. hřbetu Cézav, na jv. pak svahem Výhonu (Nové hory). Na severovýchodě depresi ohraničuje zřetelný práh mezi Novými horami a Cézavami. Na jihozápadním okraji pánve existuje podobný práh, ovšem tento je v terénu skoro neznatelný (obr. 1). Geologickým základem jz. prahu je těleso písčitých „téglü“ na 45. metru ERT řezu JK, ověřené vrtem V11 (obr. 7). Jihozápadní práh se $\mathrm{v}$ dnešní morfologii téměř neprojevuje, protože terén byl znivelován nejmladšími svahovinami zachycenými vrtem V11. Jihozápadní, a téměř jistě i sv. práh, jsou součástmi obrovského sesuvového tělesa, jehož morfologie určuje charakter celé oblasti. Mohutný sesuv, velikostně významný pro celý Výhon, inicioval vznik deprese ve své týlní části, tj. v sedle mezi Cézavami a Novými horami.

$\mathrm{Na}$ základě interpretace sedimentů, výsledků malakozoologické analýzy (Salaš et al. 2012) a srovnání s historickými záznamy (Melichárek 1929) lze vymezit dva typy prostředí a procesů, které řídily vyplňování deprese: centrální facii jezer a mokřadů (facie 2) a okrajovou facii svahových sedimentů (facie 1). Míra progradace svahovin až do centra deprese byla závislá od rozsahu svahových deformací prredevším na úbočí Nových hor, méně na úbočí Strže.

Deprese je $\mathrm{v}$ př́ičném průřezu asymetrická, což dokazuje průběh předkvartérního povrchu a tvar facie 2 (obr. 6). Centrální facie dosahuje největší mocnosti podél úpatí Cézav. Odtud se dno deprese zvedá směrem k úpatí Nových hor a v tomto směru klesá i mocnost facie 2, ačkoliv kolísavě. Radiokarbonová data kladou počátek vyplňování deprese do doby nejpozději před 3600 lety. Deprese bude pravděpodobně ještě starší, protože úplně bazální polohy centrální facie nebyly datovány. Podle geologických řezů lze nejhlubší část deprese podél úpatí Cézav, s nejvyššími mocnosti centrální facie a nejstarším zjištěným radiokarbonovým datem, interpretovat jako nejdéle existující úsek celé deprese. Ostatní radiokarbonová data ale tento koncept nepotvrzují. Chaotická laterální distribuce dat ve vrtech V9, V10 a V11 s časovým rozpětím 12 st. BC až 18. st. AD spíše ukazuje na dominantní vliv jednotlivých sesuvů. V rámci celé deprese náhle vznikala lokální depocentra, ohraničená epizodickými sesuvy.

Obr. 5: Facie vrtů V10 a V11. Modrá šipka: intraklasty; bílé šipky: drobtovitý půdní horizont; žlutá šipka: prokořenění.

Fig. 5: Facies of cores V10 and V11. Blue arrow: intraclasts; white arrows: soil crumb structure; yellow arrow: root bioturbation. 


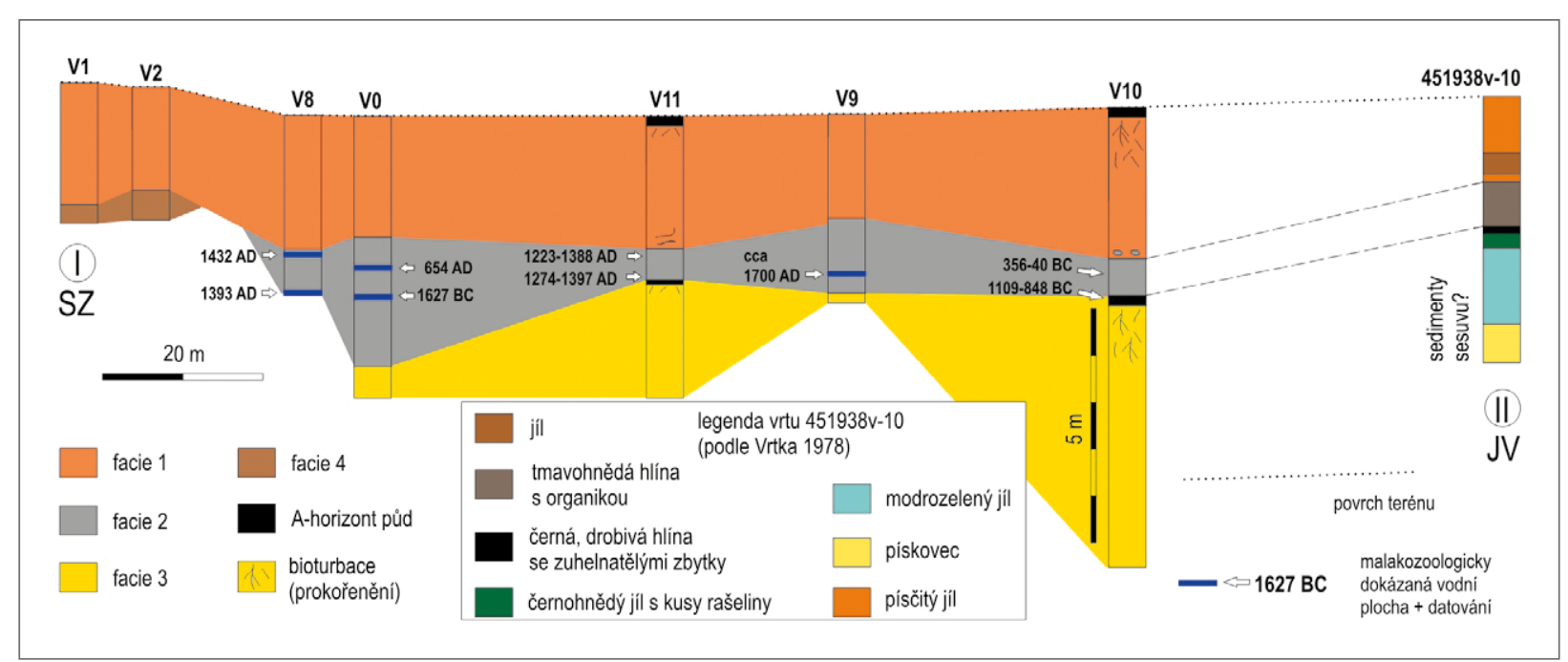

Obr. 6: Geologický řez podle vrtů. Pozice řezu viz obrázek 1.

Fig. 6: Geological cross-section according studied drillings. For location cross-sections see Fig. 1.

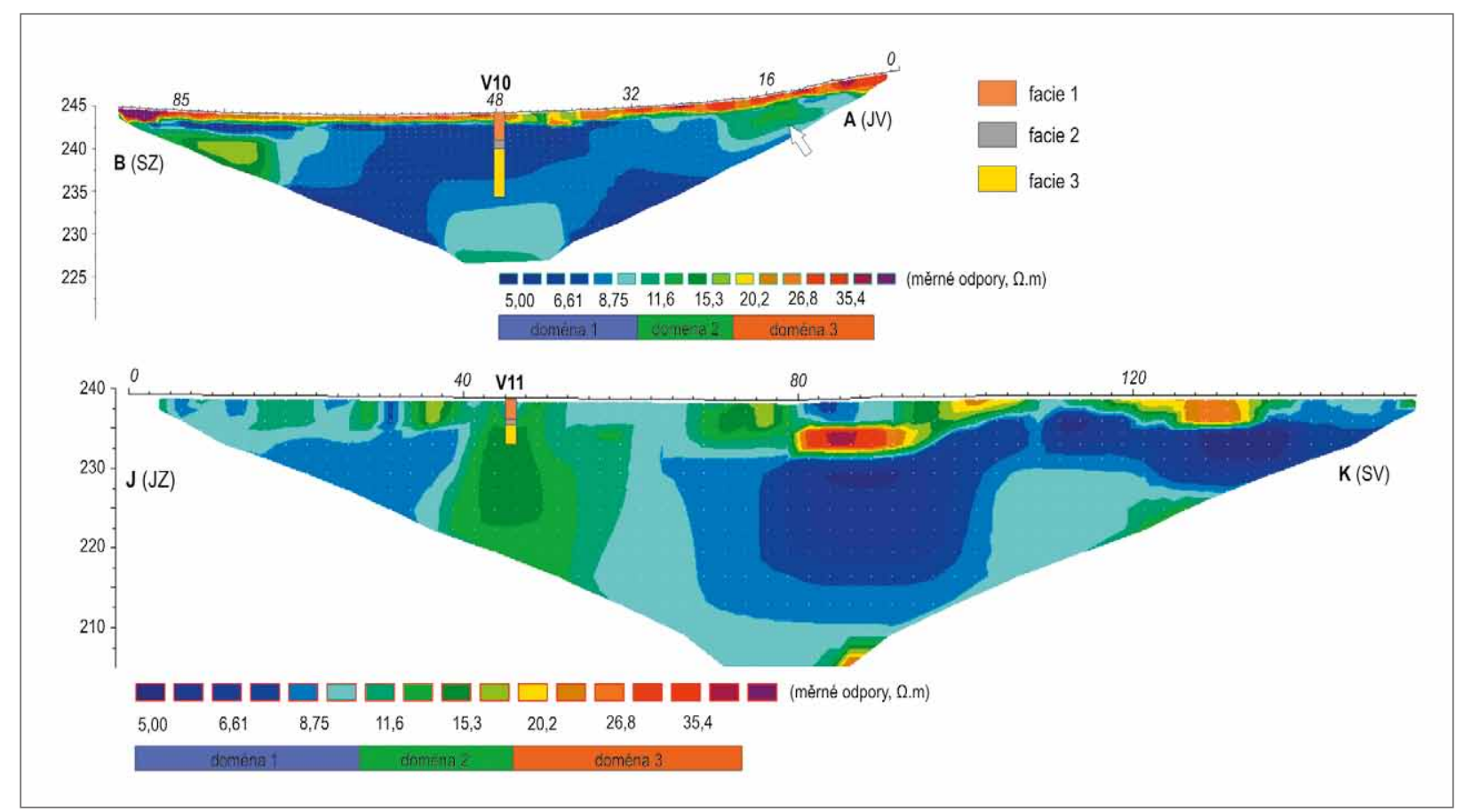

Obr. 7: ERT profily. Pozice profilů viz obrázek 1.

Fig. 7: ERT profiles. For location of cross-sections see Fig. 1

Tato dílčí depocentra hostila mokřady, prrípadně dočasná jezera. Ostrý kontakt mezi subfosilními půdami na povrchu facie 3 (podloží kvarterních sedimentů) a centrální facií 2 dokládá náhlý nástup mokřadů a jezer na dosud subaerický povrch. Tato rychlá změna patrně nastala po rapidní akumulaci svahovin. Sesuvové těleso změnilo lokální morfologii a vymezilo depocentra pro zadržení srážkové vody. Vyvýšená poloha facie $2 \mathrm{v}$ archivním vrtu 451938v-10 (Vrtek 1978, viz obr. 6) je způsobena polohou mokřadu/jezera $\mathrm{v}$ dílčím depocentru pravděpodobně na sesuvu, jehož těleso se morfologicky zvedalo nad okolní terén. Pozice centrální facie ve svahu nad sedlem podporuje roli jednotlivých sesuvů jako ústředních činitelů vyplňování deprese. Tento vývoj pokračuje dodnes, protože důsledkem pokračující degradace úbočí Výhonu vznikají mokřadní depocentra i vysoko v jeho svazích (obr. 2B, D). Bezprostředně podpovrchové svahoviny facie 1 vznikly při sesuvech v novověku, což dokazují nálezy glazované novověké keramiky (Salaš et al. 2012). Je možné, že většina novověkých svahových sedimentů facie 1 vznikla během historicky zaznamenané události roku 1774, kdy došlo k rozsáhlým sesuvům podél celého svahu Cézav, Nových hor a Záhumení (Melichárek 1929). Podle citovaného autora nastaly tyto události po vlhkých letech 1770 a 1771 a zasáhly celou studovanou oblast. Toto období spadá do chladnějšího a vlhčího období označovaného jako „malá doba ledová“ (Büntgen, Tegel, 2011). $\mathrm{V}$ důsledku těchto svahových pohybů vzrostla dočasně hladina jezera. V následujících letech opět poklesla, zčásti 
i umělým svedením vody ze studované oblasti do židlochovického vodovodu (Melichárek 1929). Reliéf Nových hor i Cézav, zobrazený ve vojenské mapě z let 1836-1852 (obr. 5 v práci Salaše et al. 2012), odpovídá dnešní podobě terénu. Velmi omezená aktivita je dnes zřejmá pouze na odlučných plochách sesuvů situovaných v nejvyšší části Nových hor a tedy nejdále od sedla (obr. 2B). Centrální jezero nemělo stálou existenci. Na mapě druhého vojenského mapování z let 1836-1852 není zakresleno, ovšem na mapě třetího vojenského mapování (1876-1878) je opět přítomno (obr. 5, $6 \mathrm{v}$ práci Salaše et al. 2012). Na leteckém snímku z roku 1953 není jezero vidět (https://kontaminace.cenia.cz/).

Dalším faktorem ovlivňujícím morfologii deprese (sedla) byla rozdílná litologie redeponovaných hornin. Zvodnělé jíly se plošně roztékaly formou bahnotoků (Hungr et al. 2001) a morfologii deprese ovlivňovaly jen mírně. Bloky pískovců a vápenců podnítily vznik relativně hlubokých, plošně omezených prohlubní, jaké jsou dnes viditelné na tělesech sesuvů na úbočí Nových hor (obr. 2D, F). Pravděpodobně podobná dílčí prohlubeň, ovšem většího měřítka, byla v mladší době bronzové využita k uložení lidských ostatků (Salaš et al. 2012).

\section{Závěry}

Výzkum ukázal, vzhledem ke značné fyzikální podobnosti jednotlivých facií, omezenou aplikovatelnost geofyzikálních metod na studované lokalitě. Tvar, rozmístění a mocnost odporově definovaných geofyzikálních domén v ERT profilech naznačovaly největší mocnosti centrální jezerně-mokřadní facie zhruba uprostřed sedla. Nově provedené vrty V9, V10 a V11 tento předpoklad nepotvrdily.
Holocenní deprese v sedle mezi Cézavami a Novými horami je geologicky predisponovaná obrovským sesuvem, jímž byla posunuta velká tělesa miocenních hornin. Za čelem sesuvu (Cézavami) vznikla deprese akumulující holocenní sedimenty, jejichž zdroje jsou okolní svahy. Deprese má asymetrický tvar s největší mocností výplně podél úpatí Cézav. Směrem k úpatí Nových hor mocnost holocenních sedimentů obecně klesá. Výplň deprese tvoří dvě sedimentární jednotky: centrální facie tmavě zbarvených jezerně-mokřadních jílovitoprachovitých sedimentů a okrajová facie jílovitoprachovitopísčitých svahovin.

Po konsolidaci reliéfu iniciálního velkého sesuvu řídily další vývoj deprese jednotlivé menší sesuvy. Po každém sesuvu nebo sérii několika sesuvů vznikly v sedle nové dílčí elevace a depocentra. Mokřady a jezírka se proto tvořily bez celkové zákonitosti v různých místech sedla. Nejmladší významnou událostí byly pravděpodobně rozsáhlé sesuvy v 70 . letech 18 . st., které jsou doloženy i historicky (Melichárek 1929). Dnešní sesuvný reliéf oblasti byl konfigurován nejpozději v polovině 19 . století. V současnosti se nestabilita terénu projevuje $\mathrm{v}$ menším rozsahu v nejvyšší části svahu Nových hor.

\section{Poděkování}

Výzkum souvislostílidského osídlení a periodického jezera na lokalitě Blučina „Cézavy“ byl podpořen programem Ministerstvem kultury $\check{C} R$ na podporu aplikovaného výzkumu a experimentálního vývoje národní a kulturní identity (NAKI II) v rámci projektu „Archeologie z nebe. Analýza a prezentace fondu dálkového prüzkumu na Moravě a ve Slezsku"s označením DG18P02OVV058.

Recenzentưm Jiřimu Otavovi (ČGS) a Janu Vítovi (ČGS) vdéčíme za cenné prripomínky, které výrazně zkvalitnily finální podobu príspěvku. 


\section{Literatura}

Bíšková, J. (2014). Archeologické a př́ŕrodní kontexty starší doby bronzové na Moravě a Slovenku (Teoretický náhled a praktická aplikace na třech př́padových studiích: Blučina, Rybník a Santovka). - MS, diplomová práce. Filozofická fakulta Masarykovy univerzity. Brno.

Büntgen, U., Tegel, W. (2011). European tree-ring data and the Medieval Climate Anomaly. - PAGES news, 19, 1, 14-15.

Everett, M. E. (2013). Near-surface applied geophysics. - Cambridge University Press.

Hungr, O., Evans, S. G., Bovis, M. J., Hutchinson, J. N. (2001). A Review of the Classification of Landslides of the Flow Type. Environmental \& Engineering Geoscience, 7, 3, 221-238. https://doi.org/10.2113/gseegeosci.7.3.221

Karkanas, P., Tourloukis, V., Thompson, N., Giusti, D., Panagopoulou, E., Harvati, K. (2018). Sedimentology and micromorphology of the Lower Palaeolithic lakeshore site Marathousa 1, Megalopolis basin, Greece. - Quaternary International, 497, 123-136. https://doi.org/10.1016/j.quaint.2018.02.037

Kontaminovaná místa: https://kontaminace.cenia.cz/

Melichárek, A. (1929). Dějiny města Blučiny. - Blučina. $472 \mathrm{~s}$.

Mussett, A. E., Khan, M. A. (2000). Looking into the earth: an introduction to geological geophysics. - Cambridge University Press. $470 \mathrm{~s}$.

Němeček, L., Smolíková, M., Kutílek, M. (1990). Pedologie a paleopedologie. - Academia. Praha. 546 s.

Pálenský, P. (1997). Soubor geologických a účelových map ČR, Geologická mapa ČR, list 24-34 Ivančice, měř. 1 : 50 000. - Český geologický ústav. Praha.

Salaš, M., Dočkalová, M., Horáčková, L., Jarošová, I., Nedbalová, J., Nývltová Fišáková, M., Petř́ik, J., Roblíčková, M., Vargová, L. (2012). Mladobronzová kumulace lidských skeletů na Cezavách u Blučiny (okr. Brno venkov) a její environmentální kontext. - Památky archeologické, 103, 1, 173-231.

Smolíková, L. (1988). Pedologie II. - Státní pedagogické nakladatelství. Praha. $294 \mathrm{~s}$.

Štěpančíková, P., Dohnal, J., Pánek, T., Łój, M., Smolková, V., Šilhán, K. (2011). The application of electrical resistivity tomography and gravimetric survey as useful tools in an active tectonics study of the Sudetic Marginal Fault (Bohemian Massif, central Europe). - Journal of Applied Geophysics, 74, 1, 69-80. https://doi.org/10.1016/j.jappgeo.2011.03.007

Vrtek, F. (1978). Zpráva o inženýrsko-geologickém průzkumu pro závlahovou nádrž „Výhon“ na katastru obce Blučina. - MS, Keramoprojekt. Brno.

Registr svahových nestabilit České geologické služby (https://mapy.geology.cz/svahove_nestability/) 